Research Journal of Applied Sciences, Engineering and Technology 16(3): 129-134, 2019

DOI: $10.19026 /$ rjaset.16.6008

ISSN: 2040-7459; e-ISSN: 2040-7467

(C) 2019 Maxwell Scientific Publication Corp.

Submitted: February 17, 2019

Accepted: March 27, 2019

Published: May 15, 2019

\title{
Research Article \\ Sidewall Thickening as Strengthening for Box-Section Laminated Bamboo Beam under Transverse Load in Shear Failure Mode
}

\author{
Karyadi, Elvan Wahyu Arlian Basuki, Prijono Bagus Susanto and Nindyawati \\ Department of Civil Engineering, Faculty of Engineering, Universitas Negeri Malang, \\ Malang, 65145, Indonesia
}

\begin{abstract}
This study aimed to compare the mechanical properties of the box-section beams made from laminated bamboo by strengthening the sidewall thickening. The base of this research was that the box-section beam had a higher bending strength than the solid cross-section with the same material volume but lack of shear strength due to the reduced sidewall thickening. A way to increase the shear strength of the box-section beam was to thicken the sidewall on the areas that receive the maximum shear force that was one-third of the span from both supports. In this research, the sidewall thickness variations in the maximum shear force areas were $2 \mathrm{~cm}$ (unreinforced group), $3 \mathrm{~cm}$, $4 \mathrm{~cm}$ and $4.8 \mathrm{~cm}$. The results of this research were; first, there was a significant increase in the shear strength of the box-section beam reinforced by the sidewall thickening compared to the unreinforced ones. Second, there was no significant difference in the modulus of elasticity of the box-section beams in all samples. Third, the average serviceability load of the box-section beams was $39.11 \%$ of the maximum load. And fourth, the sidewall thickening on one-third of the support span saved the material used compared to the thickening on the entire support span.
\end{abstract}

Keywords: Bamboo, box-section, laminated, shear, sidewall, thickening

\section{INTRODUCTION}

Bamboo can be used as a substitute for wood because their appearance and strength are similar to those of wood. According to Chaowana (2013), Asian bamboo (Dendrocalamus Asper Backer) has a flexural strength of $85.7 \mathrm{MPa}$ and a shear strength of $5.4 \mathrm{MPa}$, in which, when classified according to wood species, it belongs to a class of D70 (EN-338, 2009). Besides, bamboo has an advantage not found in wood, i.e., fast growth rates, reaching its maximum strength at a shorter period (Xiaohong and Yulong, 2005).

Previous research has suggested that bamboo is suitable for structural elements such as beams (Xiao et al., 2010; Sinha et al., 2014). A box-section beam is used as a viable alternative to a solid beam to obtain a stronger laminated bamboo beam for the same material volume because it has a greater moment of inertia (Gere and Timoshenko, 1994). Also, Karyadi and Susanto (2017) found that the box-section beam has a bending strength $48 \%$ higher than the solid cross-section for the equal volume of material.

Nevertheless, the box-section beam has a weakness which lies in its lack of shear strength because the thickness of its sidewalls is reduced. Accordingly, it makes the box-section beam could not be used as a structural element because the beams have dominant properties to receive bending and shear load.

Based on those facts, there are methods required to increase the shear strength of the box-section beam so that it could be used as a structural element. One of the methods is by thickening the sidewall areas that receive the maximum shear force. By using thickness in the thicker sidewall, it increases the shear strength of a beam because based on Eq. (1) the thicker the sidewall of a beam, the smaller shear stress happens so that the shear strength of a beam increases. Based on the description above, the purposes of this study were to compare the mechanical properties of box-section laminated bamboo beams by strengthening the sidewall thickening.

A four-point bending test indicated that the maximum shear force occurred in one-third of the span of the beam. Gere and Timoshenko (1994) performed the four-point bending testing, the shear strength of the beam can be calculated using Eq. (1) and its elastic modulus using Eq. (2):

$$
\tau=\frac{V Q}{2 t_{1} I}
$$

Corresponding Author: Karyadi, Department of Civil Engineering, Faculty of Engineering, Universitas Negeri Malang, Malang, 65145, Indonesia, Tel.: +628123321855

This work is licensed under a Creative Commons Attribution 4.0 International License (URL: http://creativecommons.org/licenses/by/4.0/). 


$$
E=\frac{2 P L^{2}}{n .162 \Delta I}+\frac{5 P L^{2}}{216 \Delta I}
$$

where,

$$
\begin{aligned}
& \mathrm{V}=\text { The shear force } \\
& \mathrm{Q}=\text { The first moment of the area } \\
& \mathrm{I}=\text { The moment of inertia } \\
& \mathrm{t}_{1}=\text { The sidewall thickness } \\
& \mathrm{E}=\text { The modulus of elasticity } \\
& \mathrm{P}=\text { The load } \\
& \mathrm{L}=\text { The span length of the beam } \\
& \mathrm{n}=\text { A comparison of the beam thickness with and } \\
& \quad \text { without reinforcement } \\
& \Delta \quad=\text { The deflection at mid-span }
\end{aligned}
$$

\section{MATERIALS AND METHODS}

The Asian bamboos used in this research originated from Malang, East Java, Indonesia. The culms of 3-4year-old bamboos were split into strips $2500 \mathrm{~mm}$ length, $20 \mathrm{~mm}$ width and $5 \mathrm{~mm}$ thickness. All bamboo strips were taken from the part closest to the bamboo skin to have uniform physical and mechanical properties. These bamboo strips were immersed in a solution of borax and boric acid mixed, each with a concentration of $1 \%$ for $4 \mathrm{~h}$ and then dried to a moisture level of less than 12\% (Mahdavi et al., 2011).

The box-section beam was produced by putting together four laminated bamboo boards as shown in Fig. 1a. The middle one-third of the total sidewall length was made thinner as in Fig. 1b. A box-section beam would be made with a variety of sidewall thickness in the support areas $\left(t_{1}\right)$ such as $2 \mathrm{~cm}, 3 \mathrm{~cm}, 4$ $\mathrm{cm}$ and $4.8 \mathrm{~cm}$. A box-section beam with a sidewall thickness of $2 \mathrm{~cm}$ is a beam without reinforcement (BTP) used as strength reference and the other beam with sidewall thickness of $3 \mathrm{~cm}$ (BDPA), $4 \mathrm{~cm}$ (BDPB)

\begin{tabular}{|c|c|c|c|c|c|c|c|}
\hline Specimens code & $\mathrm{b}(\mathrm{cm})$ & $\mathrm{h}(\mathrm{cm})$ & $\mathrm{t}_{1}(\mathrm{~cm})$ & $\mathrm{t}_{2}(\mathrm{~cm})$ & $\mathrm{t}_{3}(\mathrm{~cm})$ & $\begin{array}{l}\text { Span length } \\
(\mathrm{cm})\end{array}$ & $\begin{array}{l}\text { Total length } \\
(\mathrm{cm})\end{array}$ \\
\hline BTP 1 & 9.60 & 14.40 & 2.00 & 2.00 & 2,00 & 100 & 110 \\
\hline BTP 2 & 9.50 & 14.30 & 2.00 & 2.00 & 2,00 & 100 & 110 \\
\hline BTP 3 & 9.50 & 14.40 & 2.00 & 2.00 & 2,00 & 100 & 110 \\
\hline BDPA 1 & 9.60 & 14.30 & 3.00 & 2.00 & 2,00 & 100 & 110 \\
\hline BDPA 2 & 9.60 & 14.40 & 3.00 & 2.00 & 2,00 & 100 & 110 \\
\hline BDPA 3 & 9.60 & 14.30 & 3.00 & 2.00 & 2,00 & 100 & 110 \\
\hline BDPB 1 & 9.60 & 14.40 & 4.00 & 2.00 & 2,00 & 100 & 110 \\
\hline BDPB 2 & 9.50 & 14.30 & 4.00 & 2.00 & 2,00 & 100 & 110 \\
\hline BDPB 3 & 9.60 & 14.40 & 4.00 & 2.00 & 2,00 & 100 & 110 \\
\hline BDPC 1 & 9.50 & 14.20 & 4.75 & 2.00 & 2,00 & 100 & 110 \\
\hline BDPC 2 & 9.50 & 14.40 & 4.75 & 2.00 & 2,00 & 100 & 110 \\
\hline BDPC 3 & 9.60 & 14.40 & 4.80 & 2.00 & 2,00 & 100 & 110 \\
\hline
\end{tabular}
and $4.8 \mathrm{~cm}$ (BDPC) is a beam with reinforcement used as a comparison to know the increase in shear strength. The details of the sizes and dimensions of the boxsection beams used in this study are presented in Table 1.

The box-section beam walls were made from bamboo strips glued together (Fig. 2). The strips were bonded using the urea-formaldehyde adhesive of 2.68 $\mathrm{N} / \mathrm{m}^{2}$ and cold-pressed at $2 \mathrm{MPa}$ during $4 \mathrm{~h}$.

Table 1: Dimension of box-section beams

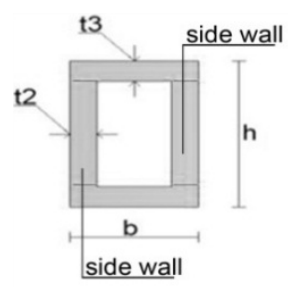

(a)

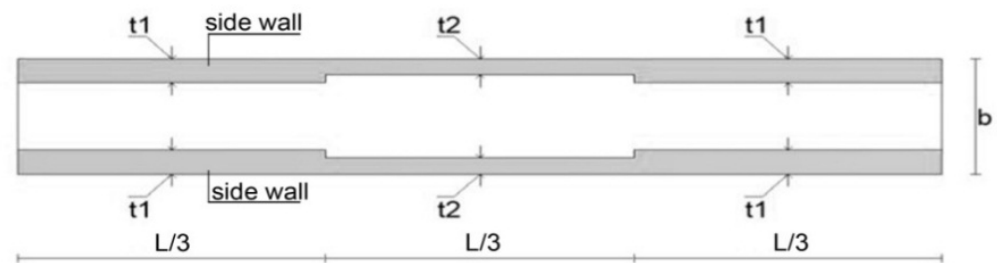

(b)

Fig. 1: (a) Cross section and (b) Longitudinal section of box-section beam

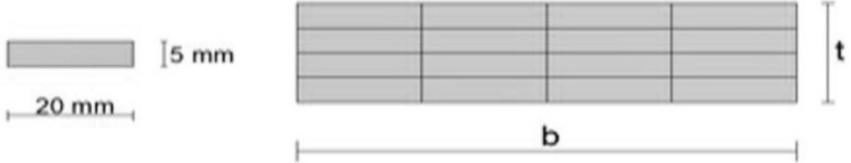

(a)

(b)

Fig. 2: (a) Sliced bamboo and (b) Sliced-laminated bamboo 


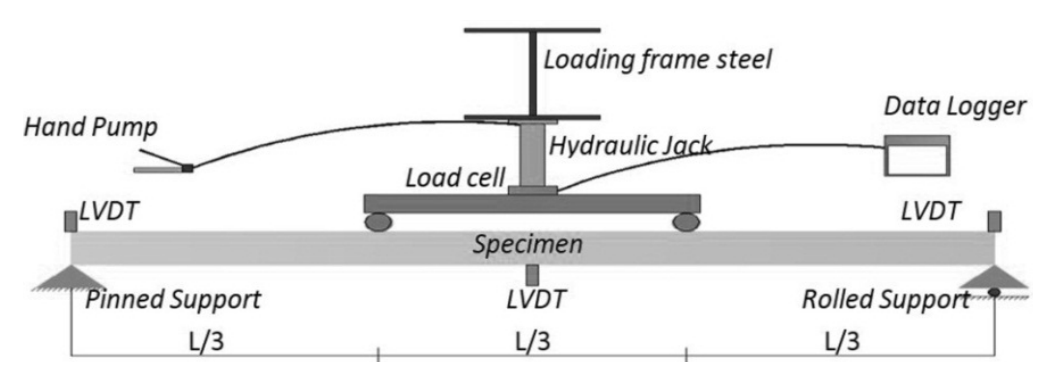

Fig. 3: The setup of the four-point bending test

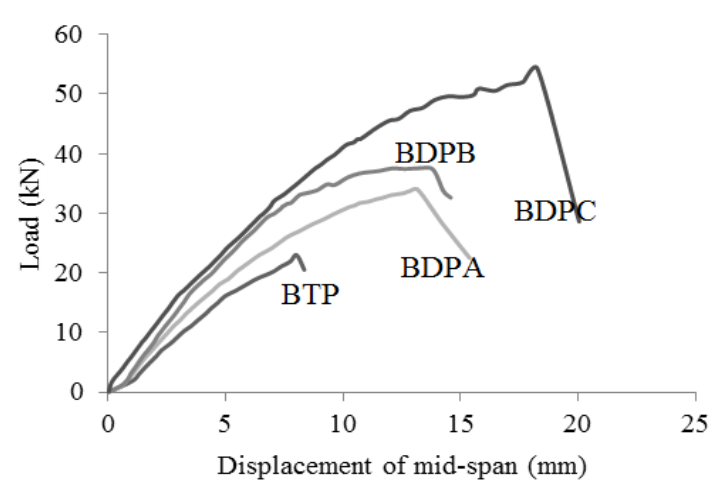

Fig. 4: The typical load and displacement relationship

Each beam was subjected to a four-point bending test complying with ASTM D-198 (2003). The beam was supported by a roller and a pinned support. The loading was carried out with a hydraulic jack of $150 \mathrm{kN}$ and measured using a $150 \mathrm{kN}$ load cell with an accuracy of $5 \mathrm{~N}$. LVDTs with a capacity of $50 \mathrm{~mm}$ and accuracy of $0.01 \mathrm{~mm}$ were installed at the middle span and at the supports to determine the beam deflection (Fig. 3).

\section{RESULTS AND DISCUSSION}

The research data included the load and displacement at the mid-span of the beams. The loading was increased gradually from zero until the beam collapsed. The load data were used to calculate shear stress, while the data about the load and displacement at the mid-span were used to calculate elastic modulus.

The typical load and displacement graph of the box-section beams in this study is presented in Fig. 4. This figure shows three important things, namely the maximum load and deflection supported by the beam, the elastic modulus of the beam and the beam failure modes. The maximum load shows an increase in line with the increase in the thickness of the beam wall. The slope of the line in the linear zone exhibits the elastic modulus of the beam and tends to increase according to the increase in thickness of the beam wall but not significant ones. Furthermore, brittle failure occurs in all test beams which are marked by a sudden change in line direction at each end of the graph.
Shear stress in the box-section beams: The results of the four-point bending test on the box-section beams made from laminated Asian bamboo presented that the shear stress ranged from 4.50-6.02 $\mathrm{MPa}$, i.e., 5.38 $\mathrm{MPa}$ on average and that the standard deviation was 0.48 $\mathrm{MPa}$ (Table 2). These data were acquired when the material of the box-section beams had the moisture content between $13.11-16.17 \%$, i.e., $14.79 \%$ on average and that the standard deviation was $1.02 \%$.

Based on the shear strength values, the laminated Asian bamboo can be considered equivalent to a wood class D70 with a shear stress value of more than 50 $\mathrm{kg} / \mathrm{cm}^{2}$ (EN-338, 2009). Further, Karyadi et al. (2014) found that the shear strength of the laminated Asian bamboo ranged from 2.86-4.85 Mpa, i.e., 4.06 $\mathrm{MPa}$ on average and a standard deviation of $0.58 \mathrm{MPa}$ under a four-point bending test. These results suggest that the Asian laminated bamboo has a widely dispersed set of data due to the high standard deviation. Also, it occurs because bamboo is a natural resource whose strength is dependent on the growth environment, climate and so forth likes wood. These were supported by the research results from Boonsta et al. (2007) that temperature and climate can affect timber strength.

Strength the box-section beam with and without reinforcement: The test results showed a significant difference in the strength between the box-section beams made from sliced laminated Asian bamboo with reinforcement and those without reinforcement. Compared to BTP, the strength of BDPA, BDPB and BDPC increased by $64.5,89.7$ and $141.3 \%$, respectively. Table 3 shows that the strength of BDPA was $64.5 \%$ higher than BTP. Compared to BDPB, BDPA had strength 25.2\% lower and BDPC had strength $51.6 \%$ higher. Figure 5 for more details.

Deflection and elastic modulus of the box-section beam: Based on the results of the four-point bending tests, the average maximum deflection of BTP, BDPA, BDPB and BDPC was 7.45, 15.4, 16.53 and $19.02 \mathrm{~mm}$, respectively. The deflection value can also be used to find elastic modulus using Eq. (2). The calculation results showed that on average the elastic modulus of BTP, BDPA, BDPB and BDPC was $11,121,12,644$, 11,640 and $14,050 \mathrm{MPa}$ respectively with the overall 
Res. J. Appl. Sci. Eng. Technol., 16(3): 129-134, 2019

Table 2: Shear stress in the box-section beams

\begin{tabular}{llllll}
\hline Specimens code & $\mathrm{I}\left(\mathrm{cm}^{4}\right)$ & $\mathrm{Q}\left(\mathrm{cm}^{3}\right)$ & $\mathrm{P}_{\max }(\mathrm{N})$ & $\Delta_{\max }(\mathrm{mm})$ & $\mathrm{t}(\mathrm{MPa})$ \\
\hline BTP 1 & $1,863.85$ & 173.12 & 20,595 & 10.60 & 4.78 \\
BTP 2 & $1,814.16$ & 169.89 & 19,215 & 8.63 & 4.50 \\
BTP 3 & $1,848.34$ & 171.88 & 23,780 & 10.53 & 5.53 \\
BDPA 1 & $2,167.83$ & 214.39 & 33,950 & 17.20 & 5.60 \\
BDPA 2 & $2,210.98$ & 217.08 & 36,815 & 20.84 & 6.02 \\
BDPA 3 & $2,167.83$ & 214.39 & 33,870 & 16.93 & 5.58 \\
BDPB 1 & $2,353.83$ & 240.64 & 41,750 & 20.67 & 5.34 \\
BDPB 2 & $2,283.74$ & 235.39 & 37,570 & 15.97 & 4.84 \\
BDPB 3 & $2,353.83$ & 240.64 & 41,300 & 21.57 & 5.28 \\
BDPC 1 & $2,266.77$ & 239.45 & 45,530 & 16.09 & 5.06 \\
BDPC 2 & $2,363.90$ & 246.24 & 53,855 & 24.80 & 5.91 \\
BDPC 3 & $2,388.79$ & 248.83 & 54,025 & 22.20 & 5.86 \\
\hline
\end{tabular}

Table 3: Comparison of strength between the box-section beams with and without reinforcement

\begin{tabular}{|c|c|c|c|}
\hline Specimens code & $\mathrm{P}_{\max }(\mathrm{N})$ & Average $P_{\max }(\mathrm{N})$ & $\begin{array}{l}\text { The increase } \mathrm{P}_{\max } \text { compared to } \\
\text { BTP }(\%)\end{array}$ \\
\hline$\overline{\text { BTP } 1}$ & 20,595 & 21,197 & 0.0 \\
\hline BTP 2 & 19,215 & & \\
\hline BTP 3 & 23,780 & & \\
\hline BDPA 1 & 33,950 & 34,878 & 64.5 \\
\hline BDPA 2 & 36,815 & & \\
\hline BDPA 3 & 33,870 & & \\
\hline BDPB 1 & 41,750 & 40,207 & 89.7 \\
\hline BDPB 2 & 37,570 & & \\
\hline BDPB 3 & 41,300 & & \\
\hline BDPC 1 & 45,530 & 51,137 & 141.3 \\
\hline BDPC 2 & 53,855 & & \\
\hline BDPC 3 & 54,025 & & \\
\hline
\end{tabular}

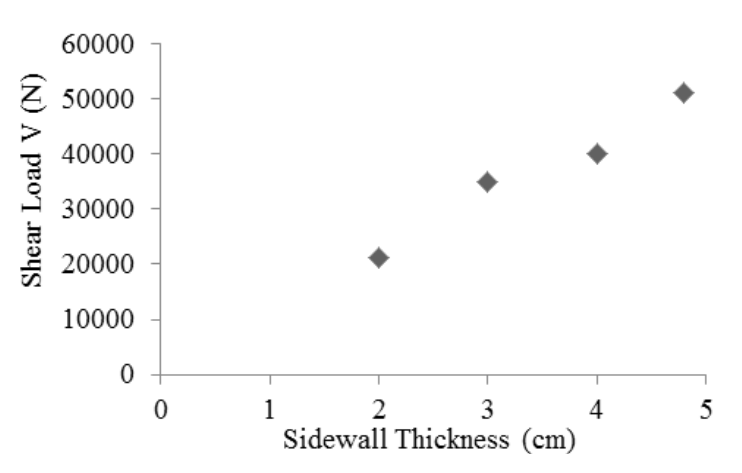

Fig. 5: Beam strength comparison

mean was $12,364 \mathrm{MPa}$ and a standard deviation of $1,728 \mathrm{MPa}$. There is no significant difference in modulus of elasticity among the group of the experiment (Table 4). According to Li et al. (2016) and Penellum et al. (2018) modulus of elasticity of laminated Moso bamboo (Phyllostachys pubescens) beam was 10,912 $\mathrm{MPa}$ and 9,490 $\mathrm{MPa}$ respectively. Others researcher found modulus of elasticity was 12,656 MPa for laminated bamboo Yushania alpine beam (Kariuki et al., 2014) and 14,504 MPa for laminated Asian bamboo beam (Karyadi and Susanto, 2017).

Serviceability load of the box-section beam: The characteristics of a structural element are determined by two components: strength and stiffness. According to EN-1995 (2004) the maximum deflection limit of beams should not exceed $\mathrm{L} / 300$. Thus, the maximum
Table 4: Deflection and elastic modulus of the beams

\begin{tabular}{llll}
\hline Specimens code & $\mathrm{P}_{\max }(\mathrm{N})$ & $\Delta_{\max }(\mathrm{mm})$ & $\mathrm{E}(\mathrm{MPa})$ \\
\hline BTP 1 & 20,595 & 7.43 & 9,661 \\
BTP 2 & 19,215 & 7.32 & 11,455 \\
BTP 3 & 23,780 & 7.63 & 12,247 \\
BDPA 1 & 33,950 & 14.39 & 14,538 \\
BDPA 2 & 36,815 & 18.82 & 11,953 \\
BDPA 3 & 33,870 & 13.00 & 11,441 \\
BDPB 1 & 41,750 & 18.11 & 9,387 \\
BDPB 2 & 37,570 & 13.15 & 13,017 \\
BDPB 3 & 41,300 & 18.34 & 12,517 \\
BDPC 1 & 45,530 & 18.72 & 13,188 \\
BDPC 2 & 53,855 & 20.05 & 14,451 \\
BDPC 3 & 54,025 & 18.28 & 14,513 \\
\hline
\end{tabular}

deflection limit in this study was $3.33 \mathrm{~mm}$. Based on the above considerations, the average percentage of serviceability load compared to the maximum load for BTP, BDPA, BDPB and BDPC was 48.61, 38.57, 34.51 and $34.74 \%$, respectively with the overall average was $39.11 \%$ and the standard deviation was $6.60 \%$ (Table 5). In support of this finding, reported by Karyadi et al. (2014) that the average service load of the box-section beams made from sliced laminated Asian Bamboo was $63 \%$ out of the maximum load in bending failure mode. These results are similar to that of the previous researcher which obtained the critical design criterion for laminated bamboo lumber structure is often deflection rather than strength (Li et al., 2016).

Material efficiency: Based on Table 3, it can be seen a considerable increase in the strength of the reinforced beams. The four-point bending test revealed that the optimum shear force occurred in one-third of the 
Res. J. Appl. Sci. Eng. Technol., 16(3): 129-134, 2019

Table 5: Serviceability load of box-section beams

\begin{tabular}{llllll} 
Specimens code & $\Delta_{\text {allowable }}(\mathrm{mm})$ & $\Delta_{\max }(\mathrm{mm})$ & $\mathrm{P}_{\max }(\mathrm{N})$ & $\mathrm{P}_{\text {service }}(\mathrm{N})$ & $\begin{array}{l}\% \mathrm{P}_{\text {service }} \text { out of } \mathrm{P}_{\max } \\
(\%)\end{array}$ \\
\hline BTP 1 & 3.33 & 7.43 & 20,595 & 9,010 & 43.70 \\
BTP 2 & 3.33 & 7.32 & 19,215 & 11,050 & 57.50 \\
BTP 3 & 3.33 & 7.63 & 23,780 & 10,260 & 44.61 \\
BDPA 1 & 3.33 & 14.39 & 33,950 & 14,180 & 41.87 \\
BDPA 2 & 3.33 & 18.82 & 36,815 & 13,030 & 35.39 \\
BDPA 3 & 3.33 & 13.00 & 33,870 & 13,060 & 38.47 \\
BDPB 1 & 3.33 & 18.11 & 41,750 & 10,030 & 24.86 \\
BDPB 2 & 3.33 & 13.15 & 37,570 & 16,060 & 42.75 \\
BDPB 3 & 3.33 & 18.34 & 41,300 & 15,000 & 35.93 \\
BDPC 1 & 3.33 & 18.72 & 45,530 & 17,070 & 39.34 \\
BDPC 2 & 3.33 & 20.05 & 53,855 & 18,130 & 33.36 \\
BDPC 3 & 3.33 & 18.28 & 54,025 & 17,080 & 31.51 \\
\hline
\end{tabular}

Table 6: Material efficiency

\begin{tabular}{lllllll}
\hline Beam & $\begin{array}{l}\text { P Research result } \\
(\mathrm{N})\end{array}$ & $\begin{array}{l}\text { P Strength } \\
\text { analysis }(\mathrm{N})\end{array}$ & $\begin{array}{l}\text { Material volume } \\
\text { found }\left(\mathrm{cm}^{3}\right)\end{array}$ & $\begin{array}{l}\text { Supposed material } \\
\text { volume }\left(\mathrm{cm}^{3}\right)\end{array}$ & $\begin{array}{l}\text { Material } \\
\text { efficiency }\left(\mathrm{cm}^{3}\right)\end{array}$ & $\begin{array}{l}\% \text { Material } \\
\text { efficiency }\end{array}$ \\
\hline BTP & $21,196.7$ & $21,312.0$ & 5,760 & 5,760 & 0 & 0 \\
BDPA & $34,878.3$ & $31,744.0$ & 7,146 & 8,640 & 1,494 & 17.28 \\
BDPB & $40,206.7$ & $42,624.1$ & 8,533 & 11,520 & 2,967 & 25.75 \\
BDPC & $51,136.7$ & $51,148.2$ & 9,642 & 13,824 & 4,182 & 30.24 \\
\hline
\end{tabular}

support span and thus the wall thickening took place only in this area. This wall thickening led to material efficiency. As calculated using Eq. (1), no significant difference was found in shear strength between the wall thickening along the entire length of the beam and the wall thickening at one-third of the support span. Accordingly, this research could stimulate material efficiency (Table 6).

As suggested by Table 6, the sidewall thickening at one-third of the support span could save up to $30.24 \%$ of materials used without reducing the shear strength of the laminated Asian bamboo beams. This method is, in fact, eminently suitable for application to structural elements.

\section{CONCLUSION}

The results of this research have led to the following conclusions:

- Compared to the unreinforced box-section laminated bamboo beams, a significant increase in strength occurred in the reinforced ones.

- There is no significant difference in modulus of elasticity of the box-section beams in the entire specimen.

- The average serviceability load of the box-section beams is $39.11 \%$ of the maximum load.

- Sidewall thickening at one-third of the support span could save on material used to compare to sidewall thickening at entire the support span.

\section{ACKNOWLEDGMENT}

This research received financial support from PNBP Universitas Negeri Malang 2018.

\section{CONFLICT OF INTEREST}

There is no conflict of interest.

\section{REFERENCES}

ASTM D-198, 2003. Annual Book of ASTM Standards Volume 04.10: D 198-02 Standard test method of Statics Test of Lumber in Structural Sizes, Section 4-11, West Conshohocken, PA.

Boonsta, M.J., J.V. Acker, B.F. Tjeerdsma and E.V. Kegel, 2007. Strength properties of thermally modified softwoods and its relation to polymeric structural wood constituents. Ann. For. Sci., 64(7): 679-690.

Chaowana, P., 2013. Bamboo: An alternative raw material for wood and wood-based composites. J. Mater. Sci. Res., 2(2): 90-102.

EN-338, 2009. Annual Book of European Standard, UNI EN-338 Structural Timber-Strength Classes, Milano.

EN-1995, 2004. Annual Book of European Standard, EN-1995-1-1: Eurocode 5: Design of Timber Structure-Part 1-1: General-Common Rules and Rules for Building, Brussels.

Gere, J.M. and S.P. Timoshenko, 1994. Mechanic of Material. 3rd Edn., Chapman and Hall, London.

Kariuki, J., T. Nyomboi and S. Mumenya, 2014. Effect of orientation and arrangement of bamboo strips on structural strength of laminated bamboo beam. Int. J. Eng. Sci. Emerg. Technol., 7(2): 555-567.

Karyadi, and P.B. Susanto, 2017. Mechanical characteristics of box-section beam made of slicedlaminated asian bamboo (Dendrocalamus Asper) in bending failure mode under transversal load. Proceedings of the AIP Conference 1887: 020062020062-8. 
Karyadi, S.M. Dewi and A. Soehardjono, 2014. Characteristics of mechanics of box-section beam made of sliced-laminated Dendrocalamus Asper under bending. Austr. J. Basic Appl. Sci. (AJBAS), 8(16): 428-433.

Li, H.T., A.J. Deeks, Q.S. Zhang and G. Wu, 2016. Flexure of laminated bamboo. BioResources, 11(1): 929-943.

Mahdavi, M., P.L. Clouston and S.R. Arwade, 2011. Development of laminated bamboo lumber: Review of processing, performance, and economical considerations. J. Mater. Civil Eng. (ASCE), 23(7): 1036-1042.
Penellum, M., B. Sharma, D.U. Shah, R.M. Foster and M.H. Ramage, 2018. Relationship of structure and stiffness in laminated bamboo composites. Constr. Build. Mater., 165: 241-246.

Sinha, A., D. Way and S. Mlasko, 2014. Structural performance of glue-laminated bamboo beams. J. Struct. Eng., 19: 1-8.

Xiao, Y., Q. Zhou and B. Shan, 2010. Design and construction of modern bamboo bridge. J. Bridge Eng., 15(5): 533-541.

Xiaohong, G. and D. Yulong, 2005. Bamboo science and culture. J. Am. Bamboo Soc., 19(1): 16-22. 